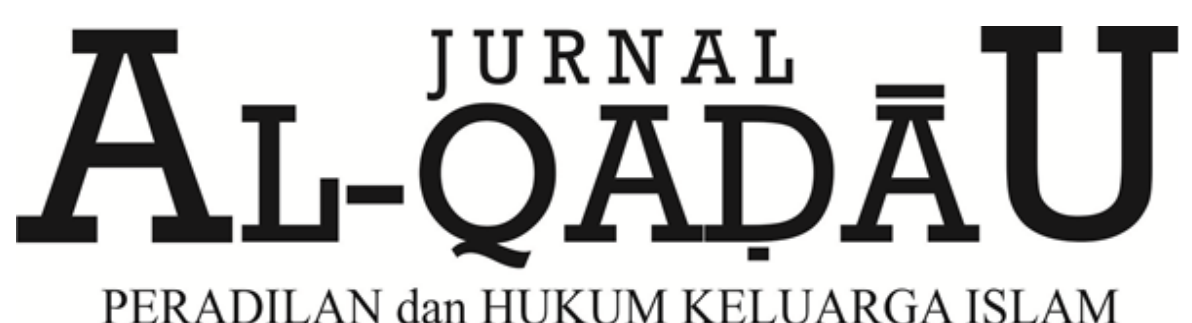

\title{
Produk Pemikiran Hukum Islam di Indonesia
}

Islamic Legal Thinking Products in Indonesia

H. Supardin

Dosen Fakultas Syariah dan Hukum UIN Alauddin Makassar

Email: supardin.pati@uin-alauddin.ac.id

\begin{tabular}{|c|c|}
\hline $\begin{array}{c}\text { Info } \\
\text { Artikkel }\end{array}$ & Abstract \\
\hline $\begin{array}{l}\text { Diterima } \\
12 \\
\text { September } \\
2017\end{array}$ & $\begin{array}{l}\text { Produk pemikiran hukum Islam di Indonesia terdiri dari produk pemikiran } \\
\text { fikih, produk pemikiran fatwa ulama, produk pemikiran keputusan } \\
\text { pengadilan (yurisprudensi), produk pemikiran undang-undang. Produk } \\
\text { pemikiran fikih merupakan jenis produk pemikiran hukum Islam di } \\
\text { Indonesia yang melahirkan berbagai jenis buku yang dipedomani. Produk } \\
\text { pemikiran fatwa ulama merupakan jenis produk pemikiran hukum Islam } \\
\text { di Indonesia yang berasal dari pemikiran ulama secara kolektif, yang } \\
\text { dituangkan dalam bentuk fatwa untuk menetapkan hukum, Produk } \\
\text { pemikiran keputusan pengadilan (yurisprudensi) merupakan jenis produk } \\
\text { pemikiran hukum Islam di Indonesia yang berasal dari pemikiran majelis } \\
\text { hakim, kemudian dihimpun dan dijadikan sebagai keputusan pengadilan. } \\
\text { Produk pemikiran undang-undang merupakan jenis produk pemikiran } \\
\text { hukum Islam di Indonesia yang berasal dari pemikiran para pakar hukum, } \\
\text { akademisi, politisi, dan instansi terkait. Produk pemikiran hukum Islam } \\
\text { tentunya diberlakukan dan ditegakkan secara komprehensip. }\end{array}$ \\
\hline
\end{tabular}

Revisi II

07

Nopember

2017

\section{Disetujui \\ 04}

Desember

2017

\section{Kata Kunci : Produk, Pemikiran, Hukum Islam}

The products of Islamic legal thought in Indonesia consist of the product of figh thought, the product of ulama's fatwa thought, the product of judicial decision thinking (jurisprudence), product of law thinking. Product jurisprudence is a type of Islamic legal thinking products in Indonesia that gave birth to various types of books that led. The product of ulama's fatwas thought is a type of Islamic legal thought product in Indonesia derived from the scholars' thought collectively, which is set forth in the form of a fatwa to establish the law. The product of judicial decision making (jurisprudence) is a type of product of Islamic legal thought in Indonesia derived from the thought of the panel of judges, then collected and made as a court decision. The product of legal thinking is a kind of product of Islamic legal thinking in Indonesia derived from the thoughts of legal experts, academics, politicians, and related institutions. The products of Islamic legal thought must be enforced and enforced comprehensively.

Keywords: Product, Thought, Islamic Law 
Supardin

\section{PENDAHULUAN}

\section{A. Latar Belakang Masalah}

Hukum Islam merupakan hukum yang bersumber dari al-Qur'an dan hadis, yang kemudian berkembang menjadi sebuah peroduk pemikiran hukum. Produk pemikiran hukum tersebut menghasilkan materi-materi hukum berdasarkan kebutuhan masyarakat. Kemudian dibentuk dan diformasi dalam sebuah konsep untuk dilaksanakan dan ditaati sebagai hasil dari produk pemikiran hukum.

Dalam teori hukum Islam biasa disebut Islamic legal theory, mengenal berbagai sumber tetapi sumber utamanya adalah al-Qur'an dan hadis sebagai sumber primer. Sedangkan sumber yang lain merupakan sumber sekunder yang berasal dari ijtihad dan interpretasi, atau pencapaian sebuah konsensus biasa disebut ijma'. ${ }^{1}$ Konsensus ini merupakan suatu pencapaian kesepakatan yang telah dianggap mewakili kepastian hukum dan atau untuk mewakili mayoritas komunitas masyarakat Islam.

Dalam sejarah sosial hukum Islam, tercatat dan tertulis pertama kali diterapkan pada abad pertama Hijriah di Madinah oleh Nabi Muhammad saw. dengan dasar konstitusi Piagam Madinah. Mukaddimah piagam tersebut tertulis, bahwa Piagam Madinah berlaku di kalangan orang-orang yang beriman dan memeluk agama Islam yang berasal dari suku Quraisy dan Yasrib. Selain orang Islam juga berlaku bagi orangorang yang mengikuti mereka, mempersatukan diri, dan berjuang bersama mereka. ${ }^{2}$ Inti dari piagam tersebut adalah perjanjian/kesepakatan antara kaum muslim dengan kaum nasrani dan yahudi (masyarakat non- muslim) yang dijadikan sebagai aturan perundang-undangan. Nabi Muhammad saw. memberi jaminan hidup terhadap mereka (non-muslim), hak milik, dan agama, serta mempunyai kebebasan penuh untuk mengamalkan ajaran agama masing-masing. Hal ini membuktikan bahwa Hukum Islam diterapkan bukan untuk memaksa dan menindas kaum yang lain, melainkan untuk diajdikan sebagai aturan yang melindungi seluruh bangsanya dalam kehidupan bermnasyarakat.

${ }^{1}$ Wael B. Hallaq, Sejarah Teori Hukum Islam, Edisi I (Cet. II; Jakarta: PT RajaGrafindo Persada, 2001), h. 1 .

${ }^{2}$ Zainal Abidin Ahmad, Piagam Nabi Muhammad saw.: Konstitusi Negara Tertulis yang Pertama di Dunia (Cet. I; Jakarta: Bulan Bintang, 1973), h. 21. 
Aturan-aturan yang merupakan hasil dari produk pemikiran hukum Islam, apabila ditinjau dari sejarah sosial hukum Islam, maka tumbuh dan berkembang sejak zaman Nabi Muhammad saw. sampai sekarang, hingga kini berlaku di Indonesia. Akan tetapi sejarah sosial hukum Islam ini muncul di dunia Barat pada akhir abad ke-20, ketika hukum Islam (fikih) itu dibukukan dalam berbagai literatur dan menampilkan potretnya yang utuh. ${ }^{3}$ Adanya pembukuan hukum Islam tersebut, umat Islam dapat mengetahui sejarah pertumbuhan dan perkembangan hukum Islam mulai dari zaman Nabi Muhammad saw. sampai zaman modern ini termasuk zaman reformasi di Indonesia.

Hukum Islam tumbuh dan berkembang di Indonesia yang diformulasi dalam empat produk pemikiran hukum, yakni fikih, fatwa ulama, keputusan pengadilan (yurisprudensi), dan undang-undang. Keempat produk pemikiran hukum tersebut dijadikan sebagai pedoman bagi umat Islam dalam kehidupan berbangsa, bernegara, dan bermasyarakat di Indonesia.

\section{B. Rumusan dan Batasan Maslah}

Berdasarkan latar belakang tersebut, maka dapat pokok permaslahan bagaimana produk pemikiran hukum Islam di Indonesia, dengan batasan sub masalah sebagai berikut:

1. Bagaimana produk pemikiran fikih?

2. Bagaimana produk pemikiran fatwa ulama?

3. Bagaimana produk pemikiran keputusan pengadilan (yurisprudensi)?

4. Bagaimana produk pemikiran undang-undang?

\section{PEMBAHASAN}

\section{A. Produk Pemikiran Fikih}

Sejarah sosial hukum Islam merupakan suatu ilmu yang mempelajari sejarah kehidupan suatu masyarakat yang ada hubungannya dengan proses lahirnya dan

${ }^{3}$ Abdul Azis Dahlan et al., Ensilopedi Hukum Islam, jilid 2 (Cet. V; Jakarta: Ichtiar Baru van Houve, 2001), h. 579. 
Supardin

berkembangnya hukum Islam. ${ }^{4}$ Adanya sejarah sosial hukum Islam sebagai sebuah ilmu, maka dapat memberi suatu arah dan tujuan sehingga dapat melahirkan produkproduk pemikiran hukum Islam di Indonesia, seperti fikih. Fikih sangat erat hubungannya dengan hukum Islam, sehingga terkadang fikih disamakan dengan hukum Islam.

Kata fikih/fiqh (فقه) dalam Kamus Al-Munawwir, fiqh (فقه) berarti mengerti, memahami ${ }^{5}$ dan secara sederhana menurut bahasa, fikih bermakna tahu dan paham. Menurut istilah fikih diartikan sama dengan agama yang disyari'atkan Allah untuk para hamba yang melengkapi hukum-hukum agama yang berpautan dengan perkataan, perbuatan, perikatan, dan lain-lain. Sedangkan menurut jumhur fuqaha, fikih diartikan sebagai ilmu yang menerangkan hukum-hukum syara' yang diperoleh dari dalil-dalil yang tafshili yakni dalil-dalil tentang hukum-hukum yang khusus yang diambil daripadanya dengan jalan ijtihad. ${ }^{6}$ Pada sumber lain, fikih menurut pengertian istilah kebanyakan fuqaha ialah "segala hukum syara' yang diambila dari Kitab Allah swt. dan Sunnah Rasulullah saw. dengan jalan mendalamkan faham dan penilikan, yakni dengan jalan ijtihad dan istinbat. ${ }^{7}$ Fikih merupakan ilmu dasar untuk memahami ajaran Islam termasuk hukum Islam yang dipahami dan diberlakukan di Indonesia. Dengan mengetahui fikih berarti mengurangi perdebatan tentang masalah khilafiah, artinya toleransi dalam khilafiah dijunjung tinggi.

Menurut H. Amir Syarifuddin, kata fikih (فقه) berarti paham yang mendalam. Bila paham dapat digunakan untuk hal-hal yang bersifat lahiriah, maka fikih berarti paham

${ }^{4}$ Abdul Azis Dahlan et al., Ensilopedi Hukum Islam, jilid 2 (Cet. V; Jakarta: Ichtiar Baru van Houve, 2001), Adapun pengertian Islam secara khusus dapat dilihat pada Cyril Glasse, Ensiklopedi Islam (Cet. III; Jakarta: PT RajaGrafindo Persada, 2002), h. 174, bahwa Islam dari kata salam yang berarti pasrah, damai, selamat, merupakan jaran Islam diwahyukan kepada Nabi Muhammad saw. antara tahun 610-632 M.

${ }^{5}$ Ahmad Warson Munawwir, Al-Munawwir Kamus Arab-Indonesia, ditelaah dan dikoreksi oleh K.H. Ali Ma'shum dan K.H. Zainal Abidin Munawwir (Cet. XIV; Surabaya: Pustaka Progrssif, 1997), h. 1067.

${ }^{6}$ T.M. Hasbi Ash-Shiddieqy, Pengantar Ilmu Fikih ( Cet. VII; Jakarta: Bulan Bintang, 1991), h. 17.

${ }^{7}$ T.M. Hasbi Ash-Shiddieqy, Hukum-hukum Fikih Islam (Cet. V; Jakarta: Bulan Bintang, 1978), h. 19 . 
yang menyampaikan ilmu zhahir kepada ilmu batin. ${ }^{8}$ Fikih tentang sesuatu berarti mengetahui batinnya sampai kedalamannya sesuatu itu. Orang yang mengetahui fikih berarti melaksanakan hukum Islam dengan keyakinan yang mendalam. Sehingga dalam berbuat dan bermuamalah termasuk dalam beribadah tidak mudah terombang-ambing oleh pengaruh di sekitarnya.

Pengetahuan yang dihasilkan dari fikih dapat menuntun manusia untuk berbuat dalam tataran hukum Islam yang diberlakukan. Maksud dari istilah hukum Islam adalah hukum yang diyakini memiliki keterkaitan dengan sumber dan ajaran Islam, yaitu hukum amali berupa interaksi sesama manusia, selain jinayat (pidana Islam). ${ }^{9}$ Namun demikian, tidak menutup kemungkinan untuk digunakan dalam pidana Islam, yang juga akan diterapkan dalam kehidupan masyarakat Islam, baik secara daerah atau lokal maupun secara nasional, seperti kekerasan dalam rumah tangga (KdRT), dan sekarang dalam tahap rancangan untuk dialihkan menjadi kewenangan Peradilan Agama.

Segala ketentuan yang berhubungan dengan ibadah murni (mahdah) tidak termasuk dalam pengertian hukum Islam pada pembahasan ini. Yang termasuk adalah hukum perdata Islam tertentu yang menjadi hukum positif bagi umat Islam, sekaligus merupakan hukum terapan bagi Peradilan Agama.

Pada Kamus Hukum dijelaskan, bahwa hukum Islam (Indonesia) atau hukum syara' ialah peraturan-peraturan dan ketentuan-ketentuan yang berkenaan dengan kehidupan berdasarkan al-Qur'an. ${ }^{10}$ Dalam Kamus Besar Bahasa Indonesia dijelaskan bahwa hukum Islam ialah peraturan dan ketentuan yang berkenaan dengan kehidupan berdasarkan al-Qur'an dan hadis. ${ }^{11}$ Artinya, hukum Islam merupakan produk fikih Indonesia.

\footnotetext{
${ }^{8}$ Amir Syarifuddin, Garis-garis Besar Fiqh (Cet. I; Jakarta: Prenada Media, 2003), h. 5.

${ }^{9}$ Amrullah Ahmad dkk., Dimensi Hukum Islam dalam Sistem Hukum Nasional (Cet. I; Jakarta: Gema Insani Press, 1996), h. 53.

${ }^{10}$ Sudarsono, Kamus Hukum, Edisi Baru (Cet. II; Jakarta: PT Rineka Cipta, 1999), h. 169.

${ }^{11}$ Departemen Pendidikan Nasional, Kamus Besar Bahasa Indonesia, Edisi Ketiga (Cet I; Jakarta: Balai Pustaka, 2001), h. 411.
} 
Supardin

Pengertian hukum Islam atau hukum syara' menurut istilah ulama usul, adalah doktrin (khitab) syari' yang bersangkutan dengan perbuatan orang-orang mukallaf secara perintah atau diperintah memilih atau berupa ketetapan (taqrir). ${ }^{12}$ Menurut T.M. Hasbi Ash-Shiddieqy, hukum Islam adalah bagian dari ilmu fikih. Karena ilmu fikih merupakan suatu kumpulan ilmu yang sangat luas pembahasannya, yang mengumpulkan berbagai ragam jenis hukum Islam dalam mengatur kehidupan untuk keperluan seseorang, golongan, dan masyarakat secara umum. ${ }^{13}$ Kemudian dalam Ensiklopedi Hukum Islam, ulama ushul fikih mendefenisikannya dengan tuntutan Allah Swt. yang berkaitan dengan perbuatan orang mukallaf, baik berupa tuntutan, pemilihan, atau menjadikan sesuatu menjadi sebab, syarat, penghalang, sah, batal, rukhsah (keringanan) atau 'azîmah (perbuatan). ${ }^{14}$ Hukum Islam dimaksudkan sebagai peraturan yang berpautan dengan kehidupan orang dewasa dalam melaksanakan perintah dan atau meninggalkan larangan berdasarkan petunjuk al-Qur'an atau hadis.

Hukum Islam di Indonesia merupakan hasil dari ijtihad ulama yang melahirkan kitab fikih yang bersumber dari al-Qur'an dan hadis, sehingga dipedomani oleh para peneliti dan penulis tentang hukum Islam di Indonesia. Hasil dari produk-produk pemikiran hukum Islam tersebut, diformulasikan dalam satu kitab atau buku yang menjadi rujukan dalam mengambil keputusan atau kebijakan dalam lembaga-lembaga perdilan dan instansi lainnya.

Produk pemikiran fikih adalah hasil dari produk hukum yang pertama dari formulasi hukum Islam melalui kitab fikih. Kitab fikih pada awalnya hasil atau kumpulan dari ceramah yang kemudian dihimpun dalam satu buku atau beberapa buku. Isi dari kumpulan ceramah tersebut meliputi berbagai aspek kehidupan manusia yang secara khusus bagi kehidupan umat Islam. Kitab fikih yang dimaksudkan adalah:

\footnotetext{
${ }^{12}$ Abdul Wahhab Khallaf, 'Ilmu Ushul al-Fiqh, Alih bahasa Noer Iskandar al-Barsany dan Moh. Tolchah Mansoer dengan Judul, Kaidah-kaidah Hukum Islam (Cet. III; Jakarta: PT Raja Grafindo Persada, 1993), h. 153.

${ }^{13}$ Teungku Muhammad Hasbi Ash-Shiddieqy, Pengantar Hukum Islam, Edisi Kedua (Cet. I; Semarang: PT Pustaka Rizki Putra, 1997), h. 9.

${ }^{14}$ Abdul Azis Dahlan et al., Ensilopedi Hukum Islam, jilid 2, h. 572.
} 
Buku yang membahas berbagai persoalan hukum Islam seperti ibadah, muamalah, pidana, peradilan, jihad, perang, dan damai berdasarkan hasil ijtihad ulama fikih dalam memahami al-Qur'an dan hadis yang dikaitkan dengan realitas yang ada dengan menggunakan berbagai metode ijtihad. ${ }^{15}$

Penyusunan kitab fikih mulanya mengalami permasalahan karena persoalan dalam masyarakat belum banyak dipertanyakan sehingga tidak sistematis. Pembukuan kitab fikih dimulai sekitar awal abad ke-2 Hijriah yang disebut zaman klasik. Penulisan kitab fikih terus berkembang, mulai dari zaman klasik sampai sekarang zaman modern.

Kalau dilihat dari produk pemikiran fikih, maka isi kitab fikih paling tidak ada tiga macam yaitu: kitab fikih lengkap, kitab fikih tematis, dan kitab fikih berbentuk fatwa. Kitab fikih lengkap yaitu membahas seluruh persoalan fikih, mencakup masalah ibadah, muamalah, perkawinan, kewarisan, perwakafan, pidana, peradilan dengan perangkat-perangkatnya, politik, jihad, perang, dan damai.

Kitab fikih lengkap biasanya diproduk dan disusun dari mazhab tertentu, dan adakalanya disusun dari berbagai mazhab dengan membandingkan pendapat-pendapat mazhab lain, misalnya “Fikih Islam Lengkap” yang ditulis oleh H. Moh. Rifa'i.

Kitab fikih tematis yaitu kitab yang hanya membahas topik tertentu, seperti masalah pemerintahan, masalah peradilan, masalah perdata, dan masalah pidana. Misalnya buku “Peradilan Agama di Indonesia” yang ditulis oleh Cik Hasan Bisri. Di zaman kalsik, kitab fikih tematis belum banyak diterbitkan. Tetapi di zaman modern ini telah banyak diterbitkan karena ilmuwan telah banyak dan semakin meluas pembidangan ilmu.

Kitab fikih berbentuk kumpulan fatwa yaitu kitab yang disusun berdasarkan hasil fatwa ulama atau sekelompok ulama tertentu. Misalnya buku "Fatwa-fatwa Seputar Ibadah Mahdah" yang ditulis oleh M. Quraish Shihab. Setiap mazhab fikih mempunyai kitab fikih standar yang menjadi sumber rujukan, baik berupa kitab fikih lengkap, kitab fikih tematis, maupun kitab fikih berupa kumpulan fatwa.

${ }^{15}$ Abdul Azis Dahlan et al., Ensilopedi Hukum Islam, jilid 2, h. 345. 
Supardin

\section{B. Produk Pemikiran Fatwa Ulama}

Setelah produk pemikiran fikih, maka produk pemikiran hukum yang kedua adalah pemikiran fatwa ulama yang merupakan hasil dari konfigurasi formulasi hukum Islam. Fatwa menurut bahasa berarti jawaban, keputusan, pendapat yang diberikan oleh mufti tentang suatu masalah; nasihat orang alim, pelajaran baik. ${ }^{16}$ Menurut ulama usul fikih, fatwa berarti pendapat yang dikemukakan oleh seoramg mujtahid atau faqih sebagai jawaban yang diajukan peminta fatwa dalam suatu kasus yang sifatnya tidak mengikat. ${ }^{17}$ Fatwa ini bersifat sanksi moral yang tidak mengikat seseorang untuk berfatwa atau meminta fatwa, dan atau untuk menerima/taat pada fatwa.

Fatwa tersebut merupakan hasil dari ijtihad seorang mufti yang bertalian dengan persoalan atau masalah yang diperhadapkan kepadanya. Fatwa ulama biasanya merupakan himbauan dari sekelompak ulama dan terkadang merupakan seruan ulama tertentu kepada masyarakat luas atau masyarakat tertentu. Oleh karena itu, produk pemikiran fikih tidak dapat dipisahkan begitu saja dengan produk pemikiran fatwa ulama, karena fikih merupakan produk hasil ijtihad ulama, dan ulama merupakan orang yang ahli dalam ilmu fikih. Hasil ijtihad ulama yang disebut fatwa terkadang dituangkan dalam bentuk buku fikih untuk dipedomani bagi umat Islam di Indonesia.

Hasil fatwa ulama di Indnesia, secara nasional dituangkan dalam bentuk fatwa MUI (Majelis Ulama Indonesia). Selain itu, ada dua fatwa ulama yang bersumber dari organisasi Islam yaitu Nahdatul Ulama dan Muhammadiyah. Kedua organisasi Islam ini, selalu mewarnai fatwa MUI di Indonesia. Hal ini dipengaruhi oleh kekuatan politik dan sistem pemerintahan/penguasa di Indonesia.

\section{Peranan Fatwa Ulama Sebagai Produk Pemikiran Hukum Islam \\ a. Klasifikasi Ulama}

Imam al-Gazali membagi ulama ke dalam dua kategori yaitu ulama dunia dan ulama akhirat. ${ }^{18}$ Ulama dunia ialah orang-orang yang dengan ilmunya bertujuan

\footnotetext{
${ }^{16}$ Departemen Pendidikan Nasional, Kamus Besar Bahasa Indonesia, Edisi Ketiga, h. 314.

${ }^{17}$ Abdul Azis Dahlan et al., Ensilopedi Hukum Islam, jilid 2, h. 326.

${ }^{18}$ Abdul Azis Dahlan et al., Ensilopedi Hukum Islam, jilid 2, h. 1842.
} 
semata-mata untuk mencapai kesenangan, kedudukan dan kehormatan di dunia saja. Sedangkan ulama akhirat adalah kebalikannya, yaitu orang-orang yang menggunakan ilmunya untuk kemaslahatan dan mencapai kebahagian akhirat.

Ulama dunia digambarkan oleh Allah dalam Q.S. Ali Imran (3): 187

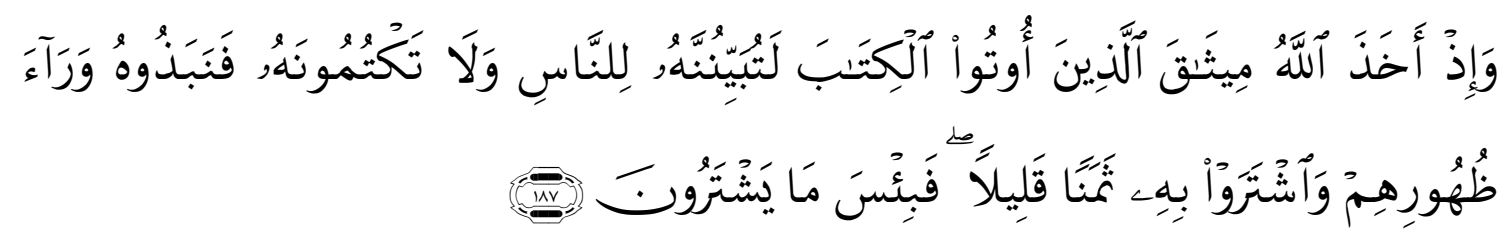

Terjemahnya:

Dan (ingatlah) ketika Allah mengambil janji dari orang-orang yang telah diberi kitab (yaitu): "hendaklah kamu menerangkan isi kitab itu kepada manusia, dan jangan kamu menyembunyikannya," lalu mereka melemparkan janji itu ke belakang punggung mereka dan mereka menukarnya dengan harga yang sedikit. Amatlah buruk tukaran yang mereka terima. ${ }^{19}$

Ulama akhirat digambarkan oleh Allah dalam Q.S. Ali Imran (3): 199 yang berbunyi:

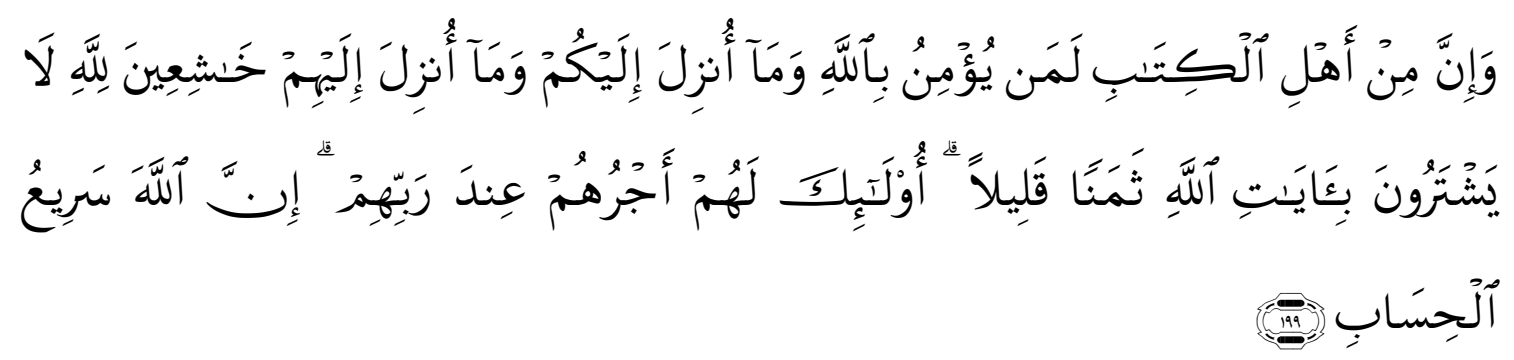

Terjemahnya:

Dan sesungguhnya di antara ahli kitab ada orang yang beriman kepada Allah dan kepada apa yang diturunkan kepada mereka sedang mereka berendah hati kepada Allah dan mereka tidak menukarkan ayat-ayat Allah dengan harga yang sedikit. Mereka memperoleh pahala di sisi Tuhannya. Sesungguhnya Allah amat cepat perhitunganNya. $^{20}$

Ulama akhirat mempunyai ciri-ciri sebagai berikut:

\footnotetext{
${ }^{19}$ Departemen Agama RI, Al-Qur'an dan Terjemahnya (Semarang: Toha Putra, 1989), h. 109.

${ }^{20}$ Departemen Agama RI, Al-Qur'an dan Terjemahnya, h. 111.
} 
Supardin

1) Tidak menggunakan ilmu pengetahuannya untuk mencapai keuntungan dunia.

2) Konsekwen terhadap perbuatannya.

3) Mengutamakan ilmu akhirat.

4) Sederhana dan zuhud.

5) Menjauhkan diri dari penguasa.

6) Tidak tergesa-gesa membenarkan fatwa.

7) Mementingkan ilmu batin dan memperhatikan gerak gerik hati yaitu berjuang melawan hawa nafsu sehingga dapat memancarkan sumber-sumber hikmah.

8) Memperkuat keyakinan.

9) Tunduk sebagai bukti takutnya kepada Allah dalam hal ihwal, pada pakaian yang dipakai, tingkah laku dan ucapannya.

10) Mementingkan ilmu yang dapat diamalkan.

11) Berperang pada mata hatinya sendiri.

12) Sangat berhati-hati dalam menghadapai hal-hal yang baru. ${ }^{21}$

Dengan demikian ciri-ciri ulama dunia adalah kebalikannya yang menghendaki dan mempergunakan ilmunya untuk mendapatklan kepuasan dunia dan kebahagiaan dunia saja. Oleh karenanya ulama semacam inilah yang selalu mempergunakan kesempatan dalam kesempitan, bahkan memutar balikkan fakta yang sebenarnya.

Ulama yang dikehendaki adalah mereka yang betul-betul menguasai ilmu keislaman dan ilmu kealaman lainnya. Dengan demikian mereka akan menguasai dan mampu memecahkan persoalan-persoalan yang dihadapi oleh masyarakat, terutama dalam pemikiran hukum Islam di Indonesia. Mereka mampu menghadapai berbagai macam tantangan yang dihadapi oleh umat dewasa ini, terutama hal ihwal yang tidak mempunyai nas secara jelas.

\section{b. Tugas dan Peran Ulama}

Dalam kehidupan masyarakat berlaku peraturan, ada perundang-undangan, hukum agama, adat istiadat, sopan santun, tata krama, dan tiap-tiap peraturan itu ada

\footnotetext{
${ }^{21}$ Imam al-Ghazali, Ihya 'Ulum al-Din, alih bahasa M. Abdul Mudjib dengan judul, Ciri-ciri Ulama Dunia Akhirat Bahaya Ilmu Pengetahuan Masa Kini (Surabaya: Mahkota, 1986), h. 28.
} 
asal usulnya serta masing-masing mengandung sanksi. Pelanggaran hukum negara akan dihukum, pelanggaran hukum agama akan mendapat siksa di akhirat. Pelanggaran adat istiadat, sopan santun dan tata krama akan mendapat sanksi dari masyarakat dan dinilai sebagai orang yang rendah dan hina dalam masyarakatnya. Dan inilah yang paling biasa ditakuti oleh masyarakat.

Tetapi justru yang tidak ditakuti oleh banyak masyarakat adalah sanksi agama, karena sifatnya abstrak yakni di akhirat kelak. Dan di sinilah yang merupakan tugas dan tanggungjawab negara termasuk para ulama. Negara boleh disebut sebagai wadah masyarakat, apabila masyarakat kuat, negarapun akan kuat. ${ }^{22}$ Dengan demikian untuk mencapai hal tersebut, maka ulama dan umara harus sejalan, tidak saling tumpang tindih antara satu dengan lainnya.

Telah dipahami bahwa ulama adalah ahli waris nabi. Oleh karenanya, sesuai dengan tugas kenabian dalam mengembangkan al-Qur'an, maka tugas dan peran ulama yang utama ada empat, yaitu:

1) Menyampaikan ajaran al-Qur'an.

2) Menjelaskan ayat-ayat al-Qur'an.

3) Memutuskan perkara yang dihadapi masyarakat.

4) Memberi contoh pengalam. ${ }^{23}$

Dengan menjalankan amanah tersebut, maka ulama mempunyai tugas yang mulia. Mustafa Said al-Khin, seorang ahli fikih kontemporer dari Suriah, mengatakan bahwa ulama akan mendapat kedudukan lebih tinggi di surga dibanding yang bukan ulama. Alasannya adalah karena ulama memiliki ilmu yang dimanfaatkannya untuk dirinya dan orang lain. ${ }^{24}$ Oleh karena itu ulama hendaknya dijaga dan dihargai. Allah telah menjelaskan dalam al-Qur'an bahwa orang yang beriman dan berilmu pengetahuan akan ditinggikan beberapa derajat dibanding orang yang beriman tetapi tidak memiliki ilmu pengetahuan dan demikian pula sebaliknya.

\footnotetext{
${ }^{22}$ H. S. Prodjokusumo dkk., Majelis Ulama Indonesia (Jakarta: Masjid Istiqlal, 1986), h. 28.

${ }^{23}$ Abdul Azis Dahlan et al., Ensilopedi Hukum Islam, jilid 2 .

${ }^{24}$ Abdul Azis Dahlan et al., Ensilopedi Hukum Islam, jilid 2.
} 
Supardin

Dalam kaitannya dengan tugas ulama, tentu berbeda dengan para nabi. Para nabi memiliki keistimewaan yang tidak dimiliki oleh para ulama. Artinya ulama tidak dapat mewarisi nabi secara sempurna. Ulama hanya sekedar berusaha untuk memahami alQur'an berdasarkan pengetahuan dan pengalaman ilmiah mereka, kemudian menyampaikan hasil pemikirannya kepada masyarakat. Dari dalam usaha inilah para ulama dapat saja mengalami kekeliruan ganda yaitu; pertama, pada saat memahami; dan kedua; pada saat memaparkan. ${ }^{25}$ Kekeliruan tersebut tidak mungkin dialami oleh nabi, sebagaimana firmannya dalam Q. S. al-Isra (17): 105

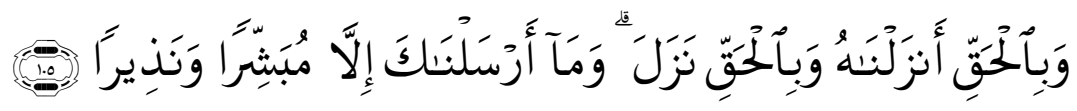

Terjemahnya:

Dan kami turunkan al-Qur'an dengan sebenar-benarnya dan al-Qur'an itu telah turun dengan membawa kebenaran. Dan kami tidak mengutus kamu, melainkan sebagai pembawa berita gembira dan pemberi peringatan. ${ }^{26}$

Oleh karena itu, peran yang dituntut dari para ulama adalah berlomba dalam berbuat kebajikan, yang titik tolaknya adalah mendekati para nabi, sehingga mampu memecahkan problem sosial yang dihadapinya. Ulama mempunyai sifat-sifat terpuji dalam masyarakat. Sifat yang dimaksud adalah sabar terhadap tema yang menyakitkan lebih baik dari mencacinya. Mencaci adalah lebih baik dari pada memutuskan silaturahmi adalah lebih baik dari pada berkelahi. ${ }^{27}$ Sifat terakhir inilah yang paling merusak dalam kehidupan berbangsa dan bernegara.

Untuk mencapai kemaslahatan dalam berbangsa dan bernegara, maka ulama mempunyai peranan yang sangat penting, yakni sebagai nara sumber dalam mengistimbatkan hukum. Ulama harus memahami betul sifat-sifat yang baik dan buruk. Pemahaman tersebut menuntut adanya usaha pemecahaan problema-problema sosial yang dihadapi. Pemecahan tidak mungkin dapat dicetuskan tanpa memahami

\footnotetext{
${ }^{25}$ M. Quaraish Shihab, Membumikan al-Qur'an (Cet. XV; Bandung: Mizan, 1418 H./1997 M), h. 375.

${ }^{26}$ Departemen Agama RI, Al-Qur'an dan Terjemahnya, h. 440.

${ }^{27}$ Mahyuddin Ibrahim, Nasehat 25 Ulama Besar (Cet. I; Jakarta: Darul Ulum, 1987), h. 258.
} 
metode integrasi antara al-Qur'an dan perkembangan masyarakat yang heterogen. Karena fatwa ulama dalam pemaparan dan penyajiannya menuntut kemampuan dalam memahami materi dan berdasarkan situasi dan kondisi sosial yang terjadi dalam masyarakat. Sementara itu pengalaman menuntut penjelmaan kongkrit isi kandungan al-Qur'an dalam bentuk tingkah laku, agar fatwa ulama itu dapat menjadi panutan bagi masyarakat luas.

Oleh karena itu fatwa ulama merupakan salah satu sumber dalam produk pemikiran hukum Islam di Indonesia. Ulama yang dimaksud adalah orang alim yang betul-betul menguasai seluk beluk hukum Islam. Dan ulama yang demikian sangat langka. Dan kelangkaan ulama ini diakibatkan alih profesi, sehingga tugas-tugas ulama semakin berat. Akibatnya banyak ulama mendapat tugas rangkap yang melebihi kemampuannya yang akhirnya mengakibatkan kelumpuhan dan ketidak berdayaan tugas-tugasnya, masyarakat bingung, ikut kepada siapa dan kemudian mengakibatkan kepada kesenjangan sosial.

\section{c. Fatwa Ulama sebagai Produk Pemikiran Hukum Islam}

Kalau ada masyarakat yang mengatasnamakan kelompok masyarakat luas berkata bahwa orientasi kepada hukum-hukum agama hendaknya dikurangi. Alasannya karena hal tersebut menimbulkan kejenuhan masyarakat terhadap hal-hal yang menimbulkan kesenjangan, maka yang dilakukan itu tidak terlalu meleset dari kebenaran. ${ }^{28}$ Memang harus diakui bahwa pelanggaran-pelanggaran dan pertentantangan-pertentangan atas hukum agama itu terjadi perbedaan yang sulit untuk disatukan. Sebagai contoh umat Islam di Indonesia selalu dua kali melaksanakan hari lebaran, baik idul fitri maupun idul adha. Mestinya persoalan semacam ini yang menyelesaikan adalah para ulama dalam hal ini Majelis Ulama Indonesia (MUI) yang mengeluarkan fatwa. Bahkan ulil amri atau organisasi-organisasi kemasyarakatan. Perbedaan-perbedaan semacam ini diakibatkan dalam penggunaan akal dan pikiran yang beraneka ragam, dan belum diadakan undang-undang yang mengatur tentang hal tersebut.

${ }^{28}$ M. Quraish Shihab, Membumikan al-Qur'an, h. 377. 
Supardin

Bagi para ulama perlu sekali mengetahui hubungan akal dan pikiran di dalam memahami agama, sehingga masing-masing mendapatkan proporsi yang sebenarnya. ${ }^{29}$ Jika dipahami urusan agama khususnya hukum Islam, karena agama itu wahyu dari Allah, maka akal dan pikiran itu ditempatkan sebagai alat pelengkap dalam memahami hukum Islam. Sehingga dengan demikian kesenjangan hukum Islam dapat diselesaikan dengan tidak membawa dampak negatif dalam masyarakat yang mempunyai komunitas heterogen.

Berbeda halnya apabila masyarakatnya mempunyai komunitas yang heterogen, misalnya dalam lingkungan kampus khususnya pesantren, mereka mendengar dan mematuhi fatwa ulama. Apa kata ulama maka itulah yang mereka laksanakan.

Untuk mecapai keberhasilan suatu fatwa, maka dikembangkan kepercayaan, nilai-nilai, norma-norma, asumsi-asumsi dasar, tradisi-tradisi dan kebiasaan-kebiasaan unik dari suatu masyarakat. Pendekatan semacam ini disebut quchi sebagai teori $Z$ yang memiliki tiga kunci pokok, yaitu:

1) Adanya saling percaya (trust).

2) Adanya hubungan timbal balik (sublety).

3) Adanya keakraban (intimacy). ${ }^{30}$

Apabila ketiga kunci pokok tersebut dilaksanakan dengan baik, maka segala fatwa dari seorang mufti akan didengar dan diterima oleh lapisan masyarakatnya, apalagi kalau bersumber dari fatwa ulama. Karena demikian halnya, maka fatwa ulama dapat dijadikan sumber pemikiran hukum Islam. Karenanya ulama harus mempunyai ilmu yang luas, sebab masyarakat banyak menghadapi problem.

Ulama salaf sangat benci terhadap orang yang menganggap remeh batas-batas atau kriteria-kriteria fatwa dan orang tidak spesialis dalam berfatwa. Seseorang yang mengakui kemuftian orang sesudah itu mengetahui kebodohan dan kekeliruannya, ia adalah orang yang termasuk berkepentingan, dan orang tersebut ikut berdosa. Para ulama telah memberikan fatwa:

\footnotetext{
${ }^{29}$ Mashuri Sirojuddin Iqbal dan Ii Sufyana M. Bakri, Mencari Cahaya dari Ilmu Ulama (Cet. I; Bandung: Sinar Baru, 1994), h. 246.

${ }^{30}$ Imron Arifin, Kepemimpinan Kyai (Cet. I; Malang: Kalimasahada Press, 1993), h. 130.
} 
Barang siapa memberikan fatwa tapi bukan ahlinya, maka orang itu seorang durhaka, dan barang siapa yang mengikutinya dia adalah orang yang durhaka pula. ${ }^{31}$

Ulama usul memberikan syarat-syarat untuk dijadikan dasar untuk menjadi mufti, yaitu:

1) Mengetahui tentang hadis yang berkaitan dengan hukum.

2) Mengetahui tentang tempat perkiraan hadis, baik syarah maupun matannya.

3) Jeli terhadap kriteria dan pendapat-pendapat.

4) Mengetahui tentang ta'adil dan tarjihnya.

5) Mampu menelaah jika membutuhkan untuk berfatwa.

6) Kalau ternyata ia memiliki kemampuan menghafal lebih baik dan lebih sempurna. ${ }^{32}$

Kriteria untuk menjadi seorang mufti (yang mengeluarkan fatwa) sangat berat, apalagi jika menyangkut persoalan ibadah yang tidak mempunyai sumber, baik alQur'an maupun dari hadis. Terlebih-lebih lagi jika berkaitan dengan hukum Islam yang dijadikan sebagai produk pemikiran hukum Islam di Indonesia yang dikenal dengan hukum nasional.

Hukum nasional di Indonesia merupakan kumpulan norma-norma hukum yang hidup dalam masyarakat yang berasal dari unsur-unsur hukum Islam, hukum adat, dan hukum modern (hukum Barat). Hukum Islam di Indonesia merupakan peraturanperaturan yang diambil dari al-Qur'an dan hadis, diformulasikan ke dalam empat produk pemikiran hukum, yaitu fikih, fatwa ulama, keputusan pengadilan, dan undangundang yang dipedomani dan diberlakukan bagi umat Islam di Indonesia. Fatwa ulama merupakan salah satu unsur pembentukan hukum Islam di Indonesia.

Secara umum telah diketahui mengapa hukum Islam tidak diberlakukan secara keseluruhan. Pada hal secara normatif, corak hukum Islam telah hidup dan berkembang di Indonesia. Hazairin dalam pidatoinya tahun 1951, ia mempersoalkan mendirikan mazhab sendiri di Indonesia, yang disebut sebagai mazhab nasional/mazhab Indonesia

\footnotetext{
${ }^{31}$ Yusuf Qardhawi, Ikut Ulama yang Mana; Etika Berfatwa dan Mufti-mufti Masa Kini (Kairo: t. tp. 1406 H./1988 M.), h. 22.
}

${ }^{32}$ Yusuf Qardhawi, Ikut Ulama yang Mana; Etika Berfatwa dan Mufti-mufti Masa Kini, h. 28. 
Supardin

yang langsung mempunyai kepentingan kemasyarakatan. Bukan berarti menyimpang dari imam-imam mazhab, karena kebutuhan dan perkembangan zaman yang selalu berubah-ubah. Penegasan itu mengandung beberapa hal yang fundamental bagi pembaharuan hukum Islam di Indonesia, yaitu:

1) Perlunya pemberian corak kenasionalan bagi perkembangan hukum Islam di Indonesia, dengan merangkumnya dalam suatu mazhab nasional yang menonjolkan hal-hal yang sifatnya spesifik.

2) Dalam rangka pemberian identitas nasional terhadap hukum Islam Indonesia, diadakan pembedaan dalam dua bidang; pertama, hukum Islam yang berkenaan dengan masalah ibadah yang sifatnya tidak langsung bersangkut paut dengan persoalan kemasyarakatan; kedua, hukum Islam langsung berkenaan dengan kemasyarakatan.

3) Mazhab Syafi'i masih hidup dan dipertahankan untuk bidang hukum Islam yang berkenaan dengan ibadah. Sedangkan bidang yang berkenaan dengan soal kemasyarakatan kita dirikan mazhab nasional/mazhab Indonesia dan melepaskan diri dari mazhab syafi'i dalam artian mengembangkan, mengubah dan memperbaiki mazhab itu.

4) Untuk pembentukan mazhab nasional diperlukan lahirnya mujtahid baru yang bercorak nasional untuk melakukan ijtihad/penerapan hukum Islam sesuai dengan situasi dan kondisi masyarakat Indonesia.

5) Pembaharuan dan pengembangan hukum Islam di Indonesia perlu disalurkan dalam suatu ikatan mazhab bukan ijtihad pribadi. ${ }^{33}$

Fatwa Hazairin tersebut merupakan salah satu fatwa ulama yang merupakan produk pemikiran hukum Islam di Indonesia. Dengan demikian, nyatalah bahwa fatwa ulama merupakan produk pemikiran hukum Islam di Indonesia. Sebagai bukti lain adalah dengan maraknya konsep pemberlakuan syariat Islam diberbagai provinsi di Indonesia, yang merupakan hasil dari pembaruan hukum Islam.

\footnotetext{
${ }^{33}$ Samsul Wahidin dan Abdurrahman, Perkembangan Ringkas Hukum Islam di Indonesia, edisi pertama (Cet. I; Jakarta: Akademi Presindo, 1984), h. 88.
} 
Pembaruan hukum Islam/hukum Islam kontemporer di Indonesia disebabkan terbukanya pintu ijtihad. Walaupun ada pendangan bahwa ijtihad itu hanya dapat dilakukan oleh ulama besar pembangun mazhab seperti Imam Malik, Imam Abu Hanifah, Iman Syafi'i, dan Imam Ahman bin Hanbal. Ulama yang membolehkan pembaruan hukum Islam memandang bahwa ijtihad bukan suatu pekerjaan yang ringan, tetapi ia merupakan suatu pekerjaan yang memerlukan daya upaya semaksimal mungkin dengan syarat yang ketat. Oleh karena itu ijtihad sangat diperlukan terutama dalam memecahkan persoalan-persoalan hukum yang setiap saat muncul dalam masyarakat, sedangkan nas-nas sangat terbatas dalam menghadapi kondisi masyarakat modern. ${ }^{34}$ Upaya pembaruan hukum Islam dewasa ini tentunya berbeda dengan ujtihad masa lalu, sebab persoalan yang dihadapi oleh umat dewasa ini semakin kompleks. Pemecahan persoalan yang semakin kompleks itu, memerlukan berbagai macam pendekatan disiplin ilmu, bukan saja pengkajian dari aspek hukum belaka, melainkan memerlukan pengkajian ilmu secara interdsipliner, seperti ilmu politik, kesehatan, ekonomi, sosial budaya, dan sebagainya.

Menyikapi persoalan-persoalan yang muncul dalam masyarakat majemuk, tidak mudah dipecahkan oleh ijtihad secara perorangan, tetapi dapat diselesaikan dan dipecahkan secara bersama dengan menggunakan logikan dan pendekatan ilmu secara interdisipliner. Oleh karena itu bentuk metode yang digunakan dalam pembaruan hukum Islam kontemporer terutama di Indonesia adalah metode kolektif dan atau metode kompilasi.

Permasalahan majemuk yang dihadapi masyarakat Islam tidaklah mudah menyelesaikan dengan metode ijtihad fardi, tetapi dengan menggunakan metode ijtihad jama'i. metode jama'i ini bisa disebut dengan metode kolektifatau metode kompilasi.

Metode ijtihad fardi merupakan ijtihad yang dilakukan secara sendiri tanpa kesepakatan mujtahid terhadap suatu permasalahan. Metode ijtihad jama’i merupakan suatu bentuk ijtihad terhadap suatu masalah yang dilakukan oleh mujtahid at au para

${ }^{34}$ Nahdiyah Syarif 'Umri, al Ijtihad fi al-Islam: Ushuluh, Ahkamuh wa Afaquh (Beirut: Mu'assasah Risalah, 1981), h. 259. 
Supardin

ahli dari berbagai disiplin ilmu. ${ }^{35}$ Metode jama'i biasa disebut dengan metode kolektif, dan dalam pembaruan hukum Islam di Indonesia disebut dengan kompilasi.

Kolektif menurut bahasa artinya secara bersama atau secara gabungan, ${ }^{36}$ dan kompilasi merupakan kumpulan yang tersusun secara teratur. ${ }^{37}$ Metode jama'i atau kolektif sering digunakan oleh Majelis Ulama Indonesia (MUI) dalam mengeluarkan fatwa tentang putusan hukum yang muncul dalam masyarakat Islam. Sedangkan metode kompilasi merupakan suatu bentuk atau metode yang digunakan sebagai pedoman dalam menemukan materi hukum, baik yang lama maupun yang baru, tetapi lebih difokuskan pada persoalan yang akurat atau masalah kekinian (tertuang dalam bentuk buku).

Bentuk metode kolektif yang digunakan oleh Majelis Ulama Indonesia ialah seperti pada kasus perkawinan beda agama, yakni: Seorang laki-laki muslim dilarang mengawini wanita bukan muslim. Tentang perkawinan antara laki-laki muslim dengan wanita ahli kitab terdapat perbedaan pendapat. Akan tetapi setelah mempertimbangkan mafsadahnya lebih besar dari maslahatnya, maka MUI memfatwakan perkawinan tersebut hukumnya haram. ${ }^{38}$ Pengharaman ini merupakan suatu pembaruan hukum Islam dengan pertimbangan, bukan saja dilihat dari segi muamalah tetapi juga dari aspek ikidah dan ibadah lainnya. Sebab kalau dalam rumah tangga terjadi dualisme agama maka keharmonisan dalam menjalankan ibadah tidak dapat dilaksanakan dengan maksimal. Misalnya yang satu membolehkan untuk melaksanakan sesuatu pekerjaan sedangkan yang lain melarang bahkan mengharamkan.

Kalau terjadi dualisme keinginan yang sifatnya mendasar, maka tujuan dari perkawinan itu tidak dapat tercapai. Sedangkan tujuan pokok dari perkawinan dalam sebuah rumah tangga adalah menciptakan keluarga yang harmonis, tenteram lahir dan

\footnotetext{
${ }^{35}$ Asafri Jaya Bakri, Konsep Maqasid Syari'ah Menurut al-Syatibi (Cet. I; Jakarta: PT RajaGrafindo Persada, 1996), h. 158.

${ }^{36}$ Departemen Pendidikan Nasional, Kamus Besar Bahasa Indonesia, Edisi Ketiga, h. 581.

${ }^{37}$ Departemen Pendidikan Nasional, Kamus Besar Bahasa Indonesia, Edisi Ketiga, h. 585.

${ }^{38}$ Majelis Ulama Indonesia, Keputusan Musyawarah Nasional II MUI-Majalah Mimbar Ulama Nomor 171 tahun XVI April 1992 (Jakarta: Sekretariat MUI, 1992), h. 66.
} 
batin. Ketenangan dapat diperoleh jika persamaan emosional secara mendasar adalah sama dalam hal ini satu agama, artinya sedangkan satu keyakinan dalam rumah tangga belum tentu melaksanakan ibadah dengan baik, apalagi kalau berbeda keyakinan.

Selain menyangkut keyakinan, juga diatur secara jelas mengenai keturunan yang sah berdasarkan hukum Islam. Majelis Ulama Indonesia juga telah menyepakati hasil kemajuan teknologi tentang bayi tabung yang tidak diatur dalam nas maupun fikih klasik, bahwa hukum dari inseminasi buatan/bayi tabung ada yang boleh/halal dan ada yang diharamkan.

Inseminasi buatan/bayi tabung hukumnya boleh atau halal apabila sperma dan ovum yang diambil dari pasangan suami istri yang sah. Inseminasi buatan/bayi tabung hukumnya haram bila sperma dan ovum diambil dari pasangan suami istri untuk istrinya yang lain, apalagi kalau bukan pasangan suami isteri. ${ }^{39}$ Dari keputusan MUI tersebut memberi peluang bagi pasangan suami istri yang sah untuk mendapatkan keturunan dengan jalan bayi tabung dari sperma kedua pasangan suami istri yang sah itu. Adanya kebolehan bayi tabung itu karena hasil dari kemajuan teknologi dan tidak ditemukan dalam fikih klasik maupun dalam al-Qur'an dan hadis, dengan syarat dari, oleh, dan untuk kedua pasangan suami istri yang sah berdasarkan hukum Islam. Keputusan MUI ini merupakan hasil dari metode pembaruan hukum Islam yang bersumber dari kesepakatan bersama yang disebut dengan metode kolektif.

Demikian halnya masalah merokok, di Indonesia kebanyakan ulama berpendapat bahwa merokok hukumnya makruh, termasuk pendapat seorang guru besar hukum Islam UIN Alauddin Makassar (H. A. Qadir Gassing). ${ }^{40}$ Larangan tentang merokok

\footnotetext{
${ }^{39}$ Surat Keputusan MUI Nomor Kep.925/XI/1990, tanggal 26 November 1990, tentang Inseminasi Buatan.

${ }^{40}$ H. A. Qadir Gassing, "Merokok dalam Kajian Islam”, materi pada diskusi bulanan ke-6 tahun VI DPP IMMIM yang bekerja sama dengan Yayasan Jantung Indonesia Cabang Utama Sulawesi Selatan tanggal 24 Juni 2006 (Makassar: DPP IMMIM, 2006), h. 5. Untuk lebih jelasnya pendapat tersebut adalah: Dalam hal merokok, sepertinya tidak ada ayat/hadis yang secara tegas melarang merokok. Oleh karena itu, dalam menetapkan hukum, pertimbangannya sepenuhnya pada maslahat dan mafsadatnya. Hal ini terlihat bahwa mafsadatnya cenderung berimbang dengan maslahatnya. Kaidah usul fikih menyatakan bahwa mencegah mafsadat didahulukan daripada menarik manfaat. Bila kaidah ini diperpegangi, maka didahulukan mencegah mafsadat (dampak negatif) dari merokok. Dengan demikian, merokok harus dilarang. Larangan itu boleh jadi makruh tetapi boleh jadi juga haram. Memilih hukum makruh atau haram dalam hal merokok di Indonesia, menjadi dilemma. Sebab bila diharamkan, ternyata banyak
} 
Supardin

tidak ada ayat dan hadis yang melarang secara tegas, namun kaidah usul fikih mempunyai pertimbangan dengan konsep mafsadat (dampak negatif) dan maslahat (dampak positif). Kedua kaidah usul fikih ini bila diperhadapkan dengan masalah hukum, maka yang lebih diutamakan adalah mencegah kerusakan atau dampak negatifnya daripada manfaatnya atau dampak positifnya. Penetapan hukum tentang merokok merupakan hasil dari produk pemikiran hukum Islam di Indonesia melalui fatwa ulama, kendatipun fatwa ulama merupakan suatu keputusan yang tidak mengikat pada masyarakat karena tidak mempunyai sanksi hukum pidana.

Pembaruan hukum Islam di Indonesia bila ditinjau dari pendekatan yurudis formal, dapat ditemukan pada Instruksi Presiden Nomor 1 tahun 1991 tentang Kompilasi Hukum Islam. ${ }^{41}$ Kompilasi inilah yang merupakan metode pembaruan hukum Islam kontemporer berdasarkan materi hukum Islam di Indonesia. Lahirnya KHI di Indonesia karena persoalan yang dihadapi umat Islam semakin kompleks dan belum memperlihatkan hukum Islam sebagai suatu hukum yang dipedomani dalam berbangsa dan bernegara.

Persoalan dikatakan kompleks, karena berlakunya hukum Islam di Indonesia tergantung pada umat Islam sebagai umat mayoritas yang merupakan faktor pendukung utama. Hukum Islam telah dilaksanakan di Indonesia selama kurun waktu ribuan tahun, namun belum memperlihatkan dirinya sebagai hukum yang utuh berdasarkan konsep dasar al-Qur'an dan Hadis. Kenyataan tersebut merupakan sebuah refleksi berlangsungnya proses Islamisasi secara berkesinambungan, yang berpacu dengan kemajuan dan perkembangan zaman. ${ }^{42}$

manfaatnya. Sedang bila dibolehkan, berarti dengan sengaja membuka jalan ke arah dampak negatifnya/mafsadatnya. Oleh karena itu, merokok cenderung hukumnya makruh.

${ }^{41}$ Lihat Republik Indonesia, Inpres Nomor 1 tahun 1991 tentang Kompilasi Hukum Islam. Dituangkan pula dalam Kepmen Agama Nomor 154 tahun 1991 tentang Pelaksanaan Inpres Nomor 1 tahun 1991 tanggal 10 Juni 1991. Presiden menginstruksikan kepada Menteri Agama untuk melaksanakan dan menyebarluaskan inpres tersebut, dan Menteri Agama mengeluarkan keputusan kepada instansi Departemen Agama dan pemerintah lainnya untuk menyebarluaskan inpres tersebut.

${ }^{42}$ H. Abdurrahman, Kompilasi Hukum Islam di Indonesia (Cet. III; Jakarta: CV Akademika Pressindo, 2001), h. 2. 
Melihat proses Islamisasi perkembangan dan pembaruan hukum Islam di Indonesia, dapat dilihat beberapa contoh pada KHI yang mengalami pembaruan, antara lain: menyangkut harta gono-gini atau harta bersama suami istri (dalam fikih klasik tidak ditemukan); bagian ayah dan ibu sama-sama bagiannya (masing-masing 1/3 dan atau 1/6, sedangkan dalam al-Qur'an bagian ayah 1/6 atau mendapat sisa); ahli waris pengganti (dalam fikih klasik tidak ditemukan ahli waris pengganti melainkan kasus munasakhah); dan sebagainya.

Kalau tidak menggunakan metode yang sama dalam proses pemberlakuan hukum Islam di Indonesia, maka akan mengakibatkan kerancuan dan ketidakberaturan materi hukum yang diberlakukan. Dengan demikian, masyarakat dengan mudah dipermainkan oleh penguasa dan atau oleh penegak hukum. Akan tetapi kalau dasar hukum dan metode yang digunakan dalam pembaruan hukum itu, hasilnya pun akan meminimalisasi kerancuan dan kecurangan dalam pemberlakuan materi hukum itu. Sebab tujuan utama dalam menerapkan hukum adalah untuk melahirkan masyarakat yang hidup teratur dan tenteram yang akhirnya hidup bahagia.

\section{Produk Pemikiran Yurisprudensi}

Yurisprudensi teridiri atas dua kata, yakni yuris dan prudensi (prudensial). Yuris artinya ahli hukum atau sarjana hukum, ${ }^{43}$ dan prudensial artinya bersifat bijaksana. ${ }^{44}$ Yurisprudensi adalah ajaran hukum melalui peradilan atau himpunan putusan hakim. ${ }^{45}$ Kata jurisprudence (Inggris) artinya ilmu hukum. ${ }^{46}$ Yurisprudensi dalam bahasa latin ialah ius/iuris berarti hukum dan prudentia berarti keahlian atau kecakapan, sehingga yurisprudensi berarti keahlian atau kemampuan dalam bidang hukum. ${ }^{47}$ Y urisprudensi

\footnotetext{
${ }^{43}$ Departemen Pendidikan Nasional, Kamus Besar Bahasa Indonesia, Edisi Ketiga, h. 1278.

${ }^{44}$ Departemen Pendidikan Nasional, Kamus Besar Bahasa Indonesia, Edisi Ketiga, h. 900.

${ }^{45}$ Departemen Pendidikan Nasional, Kamus Besar Bahasa Indonesia, Edisi Ketiga, h. 1278.

${ }^{46}$ John M. Echols dan Hassan Shadily, Kamus Inggris Indonesia (Cet. XX; Jakarta: PT Gramedia,
} 1992), h. 338.

\footnotetext{
${ }^{47}$ Abdul Azis Dahlan et al., Ensilopedi Hukum Islam, jilid 2, h. 1965 Secara luas dapat dimaknai bahwa yurisprudensi juga berarti ilmu/penerapan tentang undang-undang peradilan; dan himpunan
} 
Supardin

merupakan ilmu tentang prinsip-prinsip utama hukum yang mengkhususkan diri pada bidang hukum dalam berbagai aspeknya: analisis tradisionalnya, sejarah asal mula dan perkembangannya, serta karakter ideal hukum tersebut. ${ }^{48}$ Dalam Kamus Hukum yurisprudensi tertulis jurisprudentie (Belanda) adalah putusan-put usan pengadilan yang dapat dianggap suatu sumber hukum, karena bila sudah ada suatu yurisprudensi yang tetap, maka akan selalu diikuti oleh hakim-hakim dalam memberikan putusannya. ${ }^{49}$ Oleh karena itu, yurisprudensi merupakan serangkaian keputusan majelis hakim yang kemudian dirangkum dalam suatu putusan pengadilan untuk dipedomani oleh para hakim dalam pemberlakuan peraturan hukum untuk mengadili dan memutuskan perkara yang serupa. Yurisprudensi yang paling tinggi kekuatan hukumnya adalah keputusan Mahkamah Agung Republik Indonesia.

Produk pemikiran yurisprudensi merupakan hasil pemikiran hukum Islam dari keputusan Pengadilan Agama, keputusan Pengadilan Tinggi Agama, dan keputusan Mahkamah Agung, sehingga dijadikan sebagai hasil dari formulasi hukum Islam yang kemudian melahirkan keputusan hukum tetap dan mengikat.

Yurisprudensi sebagai salah satu dasar hukum di Indonesia, sangat memegang peranan penting terhadap pertumbuhan dan perkembangan hukum Islam. Kedudukan yurisprudensi dalam penerapan hukum Islam sangat penting, sebab yurisprudensi disusun secara sistematis dan metodologis untuk dapat memahami sumber pokok hukum Islam, yakni al-Qur'an dan hadis. Al-Qur'an dan hadis memuat peraturanperaturan dasar atau pokok-pokoknya, sehingga diperlukan alat bantu untuk lebih memahami ajaran dasar tersebut seperti yurisprudensi. Pemberlakuan yurisprudensi sebagai bagian dari jenis-jenis produk pemikiran hukum Islam, dapat menghasilkan berbagai materi hukum Islam seperti yang tersusun dalam Kompilasi Hukum Islam (KHI) di Indonesia.

keputusan-keputusan pengadilan (di bidang hukum positif: keputusan Mahkamah Agung dan Pengadilan Tinggi) yang diikuti oleh para hakim dalam mengadili/memutuskan perkara serupa.

${ }^{48}$ Abdul Azis Dahlan et al., Ensilopedi Hukum Islam, jilid 2, h. 1965.

${ }^{49}$ J.C.T. Simongkir dkk., Kamus Hukum (Cet. V; Jakarta: Bumi Aksara, 1995), h. 78. 
Gagasan untuk mengadakan Kompilasi Hukum Islam di Indonesia, mulanya dikemukakan oleh Menteri Agama Republik Indonesia, Prof. Dr. H. Munawir Sjadzali, M.A. pada bulan Februari 1985 di IAIN Sunan Ampel Surabaya. Mulai saat itu para akademisi dan praktisi hukum Islam mulai menggelinding dan mendapat respons yang positif. Malahan Presiden Republik Indonesia (Soeharto) mengambil prakarsa untuk melahirkan gagasan mengadakan Kompilasi Hukum Islam di Indonesia. Pada tanggal 25 Maret 1985, Mahkamah Agung dan Menteri Agama mengeluarkan keputusan dan menandatangani bersama di Yogyakarta berdasarkan Nomor 07/KMA/1985 dan Nomor 25 Tahun $1985 .^{50}$

Penandatanganan tersebut dilakukan oleh kedua belah pihak di depan Ketuaketua Pengadilan Tinggi Agama, Ketua-ketua Pengadilan Tinggi, dan Ketua-ketua Pengadilan Tinggi Militer se-Indonesia. Isi dari keputusan bersama tersebut adalah proyek "Pengembangan Hukum Islam melalui Yuriprudensi." Yurisprudensi itu dinamakan Kompilasi Hukum Islam yang dilaksanakan oleh sebuah tim pelaksana proyek. Tugas dari tim pelaksana proyek tersebut mengkompilasikan aturan hukum Islam yang diambil dari berbagai sumber dan mencakaup seluruh wilayah Indonesia. Sehingga pada tanggal 10 Juni 1991 keluarlah Instruksi Preseden Republik Indonesia Nomor 1 Tahun 1991 tentang Kompilasi Hukum Islam dan diperkuat oleh Keputusan Menteri Agama Republik Indonesia Nomor 154 Tahun 1991 tentang Pelaksanaan Instruksi Presiden RI Nomor 1 Tahun 1991 Tanggal 10 Juni 1991. Materi KHI tersebut memuat tiga buku, buku pertama memuat tentang perkawinan, buku kedua memuat tentang kewarisan, dan buku ketiga memuat tentang perwakafan.

Yurisprudensi tertinggi dalam hal ini Mahkamah Agung dapat membatalkan putusan pada tingkat Pengadilan Tinggi Agama. Putusan PTA tersebut dibatalkan oleh Mahkamah Agung oleh karena adanya pertimbangan hukum yang lebih kuat, sehingga Mahkamah Agung melahirkan yurisprudensi.

${ }^{50}$ J.C.T. Simongkir dkk., Kamus Hukum, h. 970. 
Supardin

\section{Produk Pemikiran Undang-Undang}

Lahirnya produk pemikiran undang-undang tidak dapat dipisahkan dengan hasil produk hukum lainnya. Undang-undang lahir setelah mendapat renspons positif dari masyarakat, terutama di kalangan lembaga legislatif dan lembaga-lembaga peradilan. Masyarakat yang taat pada hukum, berarti ia telah menerapkan peraturan perundangundangan, sebab undang-undang merupakan bagian dari tata kehidupan dalam berbangsa, bernegara, dan bermasyarakat.

Undang-undang meliputi berbagai aspek, baik aspek hukum, polititik maupun sosial-budaya lainnya. Undang-undang menurut bahasa Indonesia adalah:

Ketentuan dan peraturan negara yang dibuat oleh pemerintah (menteri, badan eksekutif, dan sebagainya), disahkan oleh parlemen (Dewan Perwakilan Rakyat, badan legislatif, dan sebagainya), ditandatangani oleh kepala negara (presiden, kepala pemerintah, raja, dan sebagainya), dan mempunyai kekuatan mengikat; aturan yang dibuat oleh orang atau badan yang berkuasa; hukum dalam arti patokan yang bersifat alamiah atau sesuai dengan sifat-sifat alam. ${ }^{51}$

Tetapi undang-undang yang dimaksudkan adalah peraturan negara yang dibuat oleh pemerintah dalam hal ini presiden bersama menterinya, disahkan oleh DPR, dan ditandatangani oleh presiden, kemudian dibuatkan peraturan pemerintah dan peraturan menteri (permen) sebagai pedoman dalam implementasi pada masyarakat.

Hasil produk pemikiran hukum telah dituangkan dalam undang-undang dan peraturan-peraturan lainnya dalam kerangka hukum Islam yang meliputi undangundang, peraturan pemerintah, keputusan presiden/peraturan presiden (perpres) atau instruksi presiden, keputusan/peraturan atau instruksi menteri (menag), dan lembaga tinggi lainnya. Peraturan-peraturan tersebut meliputi tentang: Peradilan Agama; hukum keluarga Islam (perkawinan, kewarisan, dan perwakafan); ibadah sosial ekonomi; pendidikan dan kesehatan Islami; ekonomi syari'ah/ekonomi Islami; dan peraturan lainnya. Lembaga Peradilan Agama dalam pengembangannya semakin kompleks apalagi dengan menyatunya lembaga-lembaga peradilan di Mahkamah Agung.

\footnotetext{
${ }^{51}$ Departemen Pendidikan Nasional, Kamus Besar Bahasa Indonesia, Edisi Ketiga., h. 1245.
} 
a. Peradilan Agama:

1. Staatblaad Nomor 152 Tahun 1882 Tentang Peraturan Peradilan Agama Islam di Jawa dan Madura.

2. Staatblaad Nomor 638 Tahun 1937 Jo. Nomor 639, Ordonansi Tentang Peradilan Agama untuk Sebagian Kalimantan Selatan dan Kalimantan Timur.

3. Undang-Undang Darurat Nomor 1 Tahun 1951 Tentang Tindakan-tindakan Sementara untuk Menyelenggarakan Kesatuan Susunan, Kekuasaan, dan Acara Pengadilan-pengadilan Sipil.

4. Undang-Undang Darurat Nomor 11 Tahun 1955 Tentang Perubahan UndangUndang Darurat Nomor 1 Tahun 1951 Tentang Tindakan-tindakan Sementara untuk Menye-lenggarakan Kesatuan Susunan, Kekuasaan, dan Acara Pengadilan-pengadilan Sipil.

5. Peraturan Pemerintah Nomor 45 Tahun 1957 Tentang Pembentukan Pengadilan Agama/Mahkamah Syari'ah di Luar Jawa Madura.

6. Undang-Undang Nomor 1 Tahun 1961 Tentang Penetapan Semua UndangUndang Darurat dan Semua nPeraturan Pemerintah Pengganti UndangUndang yang Sudah Ada Sebelum Tanggal 1 Januari 1961 Menjadi UndangUndang.

7. Undang-Undang Nomor 14 Tahun 1970 Tentang Pokok-pokok Kekuasaan Kehakiman.

8. Undang-Undang Nomor 35 Tahun 1999 Tentang Perubahan Atas UndangUndang Nomor 14 Tahun 1970 Tentang Ketentuan-ketentuan Pokok Kekuasaan Kehakiman.

9. Undang-Undang Nomor 7 Tahun 1989 Tentang Peradilan Agama.

10. Surat Edaran Mahkamah Agung Nomor 2 Tahun 1990 Tentang Petunjuk Pelaksanaan Undang-Undang Nomor 7 Tahun 1989 Tentang Peradilan Agama.

11. Undang-Undang Nomor 18 Tahun 2003 Tentang Advokat.

12. Undang-Undang Nomor 4 Tahun 2004 Tentang Kekuasaan Kehakiman. Undang-undang ini menghapus Undang-Undang Nomor 14 Tahun 1970 Tentang Pokok-pokok Kekuasaan Kehakiman termasuk amandemennya. 
13. Undang-Undang Nomor 3 Tahun 2006 Tentang Perubahan Atas UndangUndang Nomor 7 Tahun 1989 Tentang Peradilan Agama. Revisi UndangUndang Nomor 7 Tahun 1989 Tentang Peradilan Agama tersebut merupakan inisiatif DPR dan pemerintah. Tanggal 13 Februari 2006 diadakan raker untuk membahas RUU tersebut, dan tanggal 20 Februari 2006 dilaksanakan pembicaraan tingkat kedua sebagai pengambilan keputusan mengenai RUU tersebut, yang pada akhirnya disahkan dan diundang pada tanggal 28 Februari 2006. ${ }^{52}$ Inti dari undang-undang tersebut adalah pengembangan materi hukum terutama pasal 49 undang-undang tersebut.

b. Hukum Keluarga Islam (Perkawinan, Kewarisan, dan Perwakafan):

1) Undang-Undang Nomor 1 Tahun 1974 Tentang Perkawinan.

2) Peraturan Pemerintah Nomor 9 Tahun 1975 Tentang Pelaksanaan UndangUndang Nomor 1 Tahun 1974 Tentang Perkawinan.

3) Instrukasi Presiden Nomor 1 Tahun 1991 Tentang Kompilasi Hukum Islam.

4) Undang-Undang Nomor 32 Tahun 1954 Tentang Penetapan Berlakunya Undang-Undang Tanggal 21 November 1946 Tentang Pencatatan Nikah, Talak, Rujuk di Seluruh Daerah Luar Jawa dan Madura.

5) Peraturan Menteri Agama Nomor 3 Tahun 1975 Tentang Kewajiban Pegawai Pencatat Nikah dan Tata Kerja Peradilan Agama dalam Melaksanakan Peraturan Perundang-Undangan Perkawinan Bagi yang Beragama Islam.

6) Peraturan Pemerintah Nomor 10 Tahun 1983 Tentang Izin Perkawinan dan Perceraian Bagi Pegawai Negeri Sipil.

7) Surat Edaran Mahkamah Agung Nomor 5 Tahun 1984 Tentang Petunjuk Pelaksanaan PP. Nomor 10 Tahun 1983.

8) Peraturan Menteri Agama Nomor 2 Tahun 1987 Tentang Wali Hakim.

9) Peraturan Pemerintah Nomor 45 Tahun 1990 Tentang Perubahan Atas PP. Nomor 10 Tahun 1983.

${ }^{52}$ Redaksi Sinar Grafika, Amandemen Undang-Undang Peradilan Agama (Cet. I; Jakarta: Sinar Grafika, 2006), h. 20. 
10) Surat Edaran Badan Administrasi Negara Nomor 48 Tahun 1990 Tentang Petunjuk Pelaksanaan PP. Nomor 45 Tahun 1990 Tentang Perubahan PP. Nomor 10 Tahun 1983.

11) Surat Edaran Mahkamah Agung Nomor 2 Tahun 1994 Tentang Pengertian Pasal 177 Kompilasi Hukum Islam (ayah mendapat sepertiga bagian bila pewaris tidak meninggalkan anak, bila ada anak, ayah mendapat seperenam bagian).

12) Undang-Undang Nomor 5 Tahun 1960 Tentang Peraturan Dasar Pokok-pokok Agraria.

13) Peraturan Pemerintah Nomor 14 Tahun 1961 Tentang Permintaan dan Pemberian Izin Pemindahan Hak Atas Tanah.

14) Peraturan Pemerintah Nomor 38 Tahun 1963 Tentang Penunjukan Badanbadan Hukum yang Dapat Mempunyai Hak Milik Atas Tanah.

15) Peraturan Pemerintah Nomor 28 Tahun 1977 Tentang Perwakafan Tanah Milik.

16) Peraturan Menteri Dalam Negeri Nomor 6 Tahun 1977 Tentang Tata Pendaftaran Tanah Mengenai Perwakafan Tanah Milik.

17) Peraturan Menteri Agama Nomor 1 Tahun 1978 Tentang Peraturan Pelaksanaan PP. Nomor 28 Tahun 1977 Tentang Perwakafan Tanah Milik.

18) Keputusan Menteri Agama Nomor 73 Tahun 1978 Tentang Pendelegasian Wewenang Kepada Kepala Kantor Wilayah Departemen Agama Provinsi/Setingkat di Seluruh Indonesia.

c. Ibadah Sosial Ekonomi:

1) Undang-Undang Nomor 17 Tahun 1999 Tentang Penye-lenggaraan Ibadah Haji.

2) Undang-Undang Nomor 38 Tahun 1999 Tentang Pengelolaan Zakat.

3) Keputusan Presiden Nomor 8 Tahun 2001 Tentang Badan Amil Zakat Nasional.

4) Keputusan Menteri Agama Nomor 581 Tahun 1999 Tentang Pelaksanaan Pengelolaan Zakat. 
5) Keputusan Menteri Agama Nomor 373 Tahun 2003 Tentang Pelaksanaan Undang-Undang Nomor 38 Tahun 1999 Tentang Pengelolaan Zakat.

d. Pendidikan dan Kesehatan Islami:

1) Undang-Undang Nomor 2 Tahun 1989 Tentang Sistem Pendidikan Nasional.

2) Undang-Undang Nomor 20 Tahun 2003 Tentang Sistem Pendidikan Nasional.

3) Undang-Undang Nomor 23 Tahun 1992 Tentang Kesehatan.

e. Ekonomi Syari'ah/Ekonomi Islami:

1) Undang-Undang Nomor 7 Tahun 1992 Tentang Perbankan.

2) Undang-Undang Nomor 10 Tahun 1998 Perubahan Undang-Undang Nomor 7 Tahun 1992 Tentang Perbankan.

3) Undang-Undang Nomor 23 Tahun 1999 Tentang Bank Indonesia.

4) Surat Edaran Bank Indonesia Nomor 2 Tahun 2000 Perihal Penilaian Aktiva Produktif dalam Penghitungan Aktiva Tertimbang Menurut Risiko.

5) Peraturan Bank Indonesia Nomor 5/7/PBI/2003 Tentang Kualitas Aktiva Produkif Bagi Bank Syari’ah.

6) Peraturan Bank Indonesia Nomor 5/9/PBI/2003 Tentang Penyisihan Penghapusan Aktiva Produktif Bagi Bank Syari’ah.

f. Peraturan Lainnya:

1) Undang-Undang Nomor 18 Tahun 2001 Tentang Otonomi Khusus Bagi Provinsi Daerah Istimewa Aceh Sebagai Provinsi Nanggroe Aceh Darussalam.

2) Keputusan Presiden Nomor 11 Tahun 2003 Tentang Mahakamah Syari'ah dan Mahkamah Syar'iyah Provinsi di Provinsi Nanggroe Aceh Darussalam.

3) Qanun Provinsi Nanggroe Aceh Darussalam Nomor 7 Tahun 2004 Tentang Pengelolaan Zakat.

4) Qanun Provinsi Nanggroe Aceh Darussalam Nomor 11 Tahun 2004 Tentang Tugas Fungsional Kepolisian Daerah Nanggroe Aceh Darussalam.

5) Undang-Undang Nomor 14 Tahun 2005 Tentang Guru dan Dosen.

Salah satu sumber untuk mendapatkan pengembangan materi hukum dalam masyarakat adalah melalui sosiologi hukum, sehingga muncul paradigma sosiologi hukum, yaitu hukum diartikan dalam berbagai aspek yang meliputi: (1) hukum sebagai ilmu pengetahuan; (2) hukum sebagai suatu disiplin ilmu; (3) hukum sebagai peraturan 
perundang-undangan atau kaidah; (4) hukum sebagai tatanan hukum; (5) hukum sebagai lembaga sosial; (6) hukum sebagai alat dan petugas; (7) hukum sebagai keputusan penguasa; (8) hukum sebagai nilai; (9) hukum sebagai tindak-tanduk perbuatan; (10) hukum sebagai seni; dan lain-lain.

Secara umum dipahami bahwa hukum Islam merupakan peraturan yang telah dibakukan di Indonesia untuk dijadikan sebagai peroduk pemikiran hukum di Indonesia. Hukum Islam juga merupakan bagian dari hukum nasional, karena hukum nasional yang berlaku di Indonesia adalah bersumber dari tiga sumber hukum, yaitu hukum adat, hukum Barat, hukum Islam.

Sebenarnya hukum Islam telah lama dikenal di Indonesia yakni sejak zaman kesultanan dan penjajahan hingga pasca kemerdekaan. Tetapi hukum Islam dijadikan sebagai hukum nasional bagi umat Islam setelah diundangkannya Undang-Undang Nomor 7 Tahun 1989 Tentang Peradilan Agama pada tanggal 20 Desember 1989. Kemudian diperkuat lagi setelah penyatuan atap lembaga-lembaga peradilan di Mahkamah Agung Republik Indonesia hingga dikeluarkannya amandemen undangundang tersebut.

Hasil amandemen undang-undang tersebut berdasarkan Undang-Undang Nomor 3 Tahun 2006 Tentang Perubahan Atas Undang-Undang Nomor 7 Tahun 1989 Tentang Peradilan Agama yang diundangkan pada tanggal 20 Maret 2006. Hasil dari amandemennya adalah pengembangan materi hukum Islam di Indonesia, termasuk ekonomi syari'ah dan bagian-bagiannya telah menjadi kewenangan Peradilan Agama. Perluasan kewenangan Peradilan Agama tersebut adalah berdasarkan Undang-Undang Nomor 4 Tahun 2004 Tentang Kekuasaan Kehakiman.

Dengan demikian dapat dipahami bahwa pengembangan materi hukum Islam ke depan bukan hanya terbatas pada bidang-bidang perdata saja, tetapi juga pada bidang pidana. Misalnya, tindakan kekerasan yang terjadi dalam kehidupan rumah tangga (kdrt) ke depan akan dimuat dan diatur dalam lingkungan Peradilan Agma. Jika kasus yang terjadi dalam rumah tangga tersebut adalah umat Islam, maka yang menyelesaikan adalah Pengadilan Agama walaupun ada unsur pidananya. Hal ini terbukti dengan perluasan wilayah kewenangan Peradilan Agama pada bidang ekonomi umat Islam secara luas yang disebut ekonomi syari'ah. Undang-undang lahir adalah 
Supardin

memerlukan waktu yang cukup lama, tidak semudah membalik kedua telapak tangan, undang-undang pun membutuhkan sosialisasi pada masyarakat luas, sehingga dalam implementasinya dapat dipatuhi oleh segala lapisan masyarakat Indonesia.

\section{PENUTUP}

\section{A. Kesimpulan}

Uraian tentang jenis-jenis produk pemikiran hukum Islam di Indonesia, dapat disimpulkan sebagai berikut:

1. Produk pemikiran fikih merupakan jenis produk pemikiran hukum Islam di Indonesia yang melahirkan berbagai jenis buku yang dipedomani dalam menemukan hukum, sekaligus dijadikan sebagai sumber hukum seperti buku Kompilasi Hukum Islam (KHI) di Indonesia.

2. Produk pemikiran fatwa ulama merupakan jenis produk pemikiran hukum Islam di Indonesia yang berasal dari pemikiran ulama secara kolektif, kemudian dituangkan dalam bentuk fatwa untuk menetapkan hukum, seperti fatwa Majelis Ulama Indonesia (MUI).

3. Produk pemikiran keputusan pengadilan (yurisprudensi) merupakan jenis produk pemikiran hukum Islam di Indonesia yang berasal dari pemikiran majelis hakim, kemudian dihimpun dan dijadikan sebagai keputusan pengadilan. Keputusan pengadilan tersebut dijadikan sebagai sumber untuk menetapkan hukum, dipedomani oleh para hakim sebagai sebagai sumber hukum terutama yang masalah-masalah baru yang serupa dengan yurisprudensi tersebut. Keputusan pengadilan/mahkamah itu adalah sifatnya mengikat bagi hakim dan para pencari keadilan.

4. Produk pemikiran undang-undang merupakan jenis produk pemikiran hukum Islam di Indonesia yang berasal dari pemikiran para pakar hukum, akademisi, politisi, dan instansi terkait. Hasil dari pemikiran hukum tersebut dirancang oleh eksekutif (pemerintah); dibahas, diputus, dan ditetapkan oleh legislatif (DPR); disahkan oleh presiden. Undang-undang tersebut tidak serta merta dilaksanakan/diterapkan, karena harus menunggu petunjuk teknis baik berupa peraturan pemerintah (PP) 
maupun keputusan menteri (kepmen) kini disebut sebagai peraturan menteri (permen), sehingga bersifat mengikat.

\section{B. Implikasi}

Jenis-jenis produk pemikiran hukum Islam di Indonesia, yang meliputi: produk pemikiran fikih, produk pemikiran fatwa ulama, roduk pemikiran keputusan pengadilan (yurisprudensi), dan produk pemikiran undang-undang, kiranya dapat diberlakukan dan ditegakkan secara jujur dan adil. Untuk dapat merealisasikan kejujuran dan keadilan dalam penerapan peraturan perundang-undangan di Indonesia, tergantung aparat penegak hukumnya. Namun di balik itu, masyarakat secara luas pun hendaknya mematuhi segala hukum perundang-undangan yang berlaku, agar tujuan negara dapat tercapai yakni mewujudkan masyarakat adil dan makmur. Akhirnya, semoga tulisan ini bermanfaat dan mendapat rida Allah swt. 


\section{DAFTAR PUSTAKA}

Al-Qur'an.

Abdurrahman, H. Kompilasi Hukum Islam di Indonesia. Cet. III; Jakarta: CV Akademika Pressindo, 2001.

Ahmad, Amrullah. dkk. Dimensi Hukum Islam dalam Sistem Hukum Nasiona.I(Cet. I; Jakarta: Gema Insani Press, 1996.

Ahmad, Zainal Abidin. Piagam Nabi Muhammad saw.: Konstitusi Negara Tertulis yang Pertama di Dunia. Cet. I; Jakarta: Bulan Bintang, 1973.

Arifin, Imron. Kepemimpinan Kyai. Cet. I; Malang: Kalimasahada Press, 1993.

Bakri, Asafri Jaya. Konsep Maqasid Syari'ah Menurut al-Syatibi. Cet. I; Jakarta: PT RajaGrafindo Persada, 1996.

Dahlan, Abdul Azis et al. Ensilopedi Hukum Islam. Cet. V; Jakarta: Ichtiar Baru van Houve, 2001.

Departemen Agama RI. Al-Qur'an dan Terjemahnya. Semarang: Toha Putra, 1989.

Departemen Pendidikan Nasional. Kamus Besar Bahasa Indonesia. Edisi Ketiga. Cet I; Jakarta: Balai Pustaka, 2001.

Echols, John M. dan Hassan Shadily. Kamus Inggris Indonesia. Cet. XX; Jakarta: PT Gramedia, 1992.

Gassing, H. A. Qadir. “Merokok dalam Kajian Islam”, materi pada diskusi bulanan ke6 tahun VI DPP IMMIM yang bekerja sama dengan Yayasan Jantung Indonesia Cabang Utama Sulawesi Selatan tanggal 24 Juni 2006. Makassar: DPP IMMIM, 2006.

Al-Ghazali, Imam. Ihya 'Ulum al-Din. Alih Bahasa M. Abdul Mudjib dengan judul, Ciri-ciri Ulama Dunia Akhirat Bahaya Ilmu Pengetahuan Masa Kini. Surabaya: Mahkota, 1986.

Glasse, Cyril. Ensiklopedi Islam. Cet. III; Jakarta: PT RajaGrafindo Persada, 2002.

Ibrahim, Mahyuddin. Nasehat 25 Ulama Besar. Cet. I; Jakarta: Darul Ulum, 1987.

Iqbal, Mashuri Sirojuddin dan Ii Sufyana M. Bakri. Mencari Cahaya dari Ilmu Ulama. Cet. I; Bandung: Sinar Baru, 1994. 
Hallaq, Wael B. Sejarah Teori Hukum Islam, Edisi I. Cet. II; Jakarta: PT RajaGrafindo Persada, 2001 .

Khallaf, Abdul Wahhab. 'Ilmu Ushul al-Fiqh. Alih bahasa Noer Iskandar al-Barsany dan Moh. Tolchah Mansoer dengan Judul, Kaidah-kaidah Hukum Islam. Cet. III; Jakarta: PT Raja Grafindo Persada, 1993.

Mahkamah Agung Republik Indonesia. Yurisprudensi. Jakarta: Mahkamah Agung, 2002.

Majelis Ulama Indonesia. Keputusan Musyawarah Nasional II MUI-Majalah Mimbar Ulama Nomor 171 tahun XVI April 1992. Jakarta: Sekretariat MUI, 1992.

Munawwir, Ahmad Warson. Al-Munawwir Kamus Arab-Indonesia, ditelaah dan dikoreksi oleh K.H. Ali Ma'shum dan K.H. Zainal Abidin Munawwir. Cet. XIV; Surabaya: Pustaka Progrssif, 1997.

Prodjokusumo H. S. dkk. Majelis Ulama Indonesia. Jakarta: Masjid Istiqlal, 1986.

Qardhawi, Yusuf. Ikut Ulama yang Mana; Etika Berfatwa dan Mufti-mufti Masa Kini. Kairo: t. tp. 1406 H./1988 M.

Redaksi Sinar Grafika. Amandemen Undang-Undang Peradilan Agama. Cet. I; Jakarta: Sinar Grafika, 2006.

Republik Indonesia. Inpres Nomor 1 tahun 1991 tentang Kompilasi Hukum Islam. Dituangkan pula dalam Kepmen Agama Nomor 154 tahun 1991 tentang Pelaksanaan Inpres Nomor 1 tahun 1991 tanggal 10 Juni 1991.

-------. Undang-Undang Nomor 7 Tahun 1987 Tentang Peradilan Agama.

-------. Undang-Undang Nomor 4 Tahun 2004 Tentang Kekuasaan Kehakiman.

-------. Undang-Undang Nomor 3 Tahun 2006 Tentang Perubahan Atas UndangUndang Nomor 7 Tahun 1987 Tentang Peradilan Agama.

Ash-Shiddieqy, T.M. Hasbi. Hukum-hukum Fikih Islam. Cet. V; Jakarta: Bulan Bintang, 1978.

------. T.M. Hasbi. Pengantar Ilmu Fikih. Cet. VII; Jakarta: Bulan Bintang, 1991.

------. Pengantar Hukum Islam. Edisi ke-2. Cet. I; Semarang: PT Pustaka Rizki Putra, 1997. 
Produk Pemikiran Islam di Indonesia

Supardin

Shihab, M. Quaraish. Membumikan al-Qur'an. Cet. XV; Bandung: Mizan, 1418 H/1997 M.

Simongkir, J.C.T. dkk. Kamus Hukum. Cet. V; Jakarta: Bumi Aksara, 1995.

Sudarsono. Kamus Hukum. Edisi Baru. Cet. II; Jakarta: PT Rineka Cipta, 1999.

Syarifuddin, Amir. Garis-garis Besar Fiqh. Cet. I; Jakarta: Prenada Media, 2003.

Surat Keputusan MUI Nomor Kep.925/XI/1990, tanggal 26 November 1990, tentang Inseminasi Buatan.

'Umri,Nahdiyah Syarif. al Ijtihad fi al-Islam: Ushuluh, Ahkamuh wa Afaquh. Beirut: Mu'assasah Risalah, 1981.

Wahidin, Samsul dan Abdurrahman. Perkembangan Ringkas Hukum Islam di Indonesia. Edisi I. Cet. I; Jakarta: Akademi Presindo, 1984. 